\title{
Kuvakielen funktioista Aleksis Kiven Kullervossa
}

Se aika, jonka Aleksis Kivi työskenteli Kullervon parissa, kaikkiaan noin viisi vuotta, muodostui hänen kirjailijankehityksensä kannalta nimenomaan dramaatikkona aivan ratkaisevan kypsymisen kaudeksi. Näin on todettava, vaikka meillä ei ole lähimainkaan täydellistä tietoa hänen sisäisestä kehityksestään tuon vaiheen aikana. Päätelmän tekeekin oikeutetuksi ennen kaikkea se, että Nummisuutarit kasvoi lopulliseen muotoonsa jotenkin samanaikaisesti. Viimeksi mainitussa me tietysti näemme nerollisen luomisvoiman jo täyteen mittaansa kypsyneenä. Toteamme senkin, miten kirjailija oli kyennyt sulattamaan muotoainekset suurimittaisen taiteellisen organismin eläviksi jäseniksi ja luomaan henkilökuvia, jotka monitahoisessa sisäisessä rikkaudessaan kuvastelevat niiden rakennusainesten runsautta, joista tuon draaman kokonaisuus punoutuu.

Mestarikomediaan verrattuna Kullervo tuntuu vakain ponnistuksin toteutetulta kokeilulta, jonka merkitys on yleisesti tunnettu. Erityistä painottamista ansaitsee se, että sen kiintoisuus kirjallisuutemme tyylihistorian kannalta on aivan poikkeuksellista laatua. Voinee väittää, että tekijä on siinä vain sangen vähäiseltä osalta voinut nojautua omakieliseen tyyliperinteeseen; monessakin mielessä ratkaisevin ja olennaisin on ollut luotava miltei alusta. Tietysti aihe oli laillaan valmiina, vieläpä Fredrik Cygnaeus oli sitä sekä esteettiseltä että psykologiselta kannalta nerokkaasti valaissut; totta on myös, että Kalevalan runosikermä antoi kieli- ja tyylimateriaalia kirjailijan käyttöön. Mutta on muistettava, että näytelmän asettamat vaatimukset ja tavoitteet ovat niin täysin poikkeukselliset ja omalaatuiset 
alkuperäiseen eeppiseen runoon verrattuna, että nuo ainekset saattoivat uudelleen luojan työpajassa monta kertaa merkitä pikemminkin ylimääräisten hankaluuksien kuin helpotusten tuojaa. Syntymässä olevaa suomalaista draamasanontaa ajatellen eivät myöskään aikaisemmat yrittelijät ja heidän jotenkin primitiiviset aikaansaannoksensa kyenneet antamaan juuri mitään merkityksellistä, ratkaisevasti enemmän sentään kirjailijan erinomaisesti tuntema kansanomainen puhetraditio.

Ei näin ollen kannata ihmetellä, että Kullervossa aavistelee jotakin kuin ulkopuolisesti luotua ja että kompositiota, tavanomaisella lailla arvioituna, on pidettävä osaksi kypsymättömänä, jollakin tavoin rosoisena. Pikemminkin kummastuttaa, että toiminnan linja on joka tapauksessa selkeästi ajateltu ja draamallinen logiikka on pyritty saamaan miltei kaikin kohdin pitäväksi. Sen sijaan dialogiin on tullut ehkä liian suuressa määrin ulkoapäin ohjattua teatterikieltä, eikä sanallinen ilmaus taivu luonteenkuvauksen kannattajaksi niin saumattomasti kuin sopisi odottaa. Tämä puoli osuu silmään sitäkin terävämmin, kun lähimmäksi vertailujen kohteeksi tarjoutuu kuin olosuhteiden pakosta Nummisuutarit.

Tutkijat ovat Kullervon yhteydessä joutuneet toteamaan Shakespearen, nimenomaan Hamletin vaikutuksen. Haluan viitata asiaan hiukan toiselta kannalta kuin aikaisemmin on tehty. Näytelmässä käytetyn aiheen traaginen ylevyys edellytti sellaista draamallista pukua, joka ei kerta kaikkiaan voinut perustua pelkästään kansan puhekieleen ja jossa ei myöskään, aiheen eräänlaisen pakanallisen dekoratiivisuuden takia, sopinut käyttää hyväksi uskonnollisen kielen Iuomia tyylitottumuksia. Kivi koetti ratkaista pulman niin, että hän otti lähtökohdakseen ensisijaisesti ne tyylitasot, jotka hän Shakespearen näytelmistä ilmeisesti erittäin hyvin tunsi. Käyttöön tulivat ennen kaikkea seuraavat: retoris-pateettinen, ironinen ja kyyninen, arkipäiväinen ja raaka, mielipuolen puhe sekä pintapuolisen leikinlaskun käyttämä puhe. Niiden soveltaminen suomenkieliseen näytelmään ei kuitenkaan voinut tapahtua ilman vaikeuksia, osaksi jo siitä syystä, että Kiven kuvaamassa sosiaalisessa miljöössä ei ollut luontevaa perustaa sellaisille yhteiskunnallisille vastakohdille, joiden olemassaoloa ne eräiltä osin edellyttivät. Ne olivat kuitenkin draamallisessa käytännössä koeteltuja ja kuljettivat osuvasti mukanaan myös tiettyjä tyyppikontrasteja. Muokkaamattomassa maaperässä kirjallis- 
draamallista viljelyä aloittelevalle ne siten tarjosivat käteen suorastaan konkreettisia välineitä, joiden avulla oman äidinkielen taipuisuutta näytelmällisiin tarkoituksiin sopi tunnustella. Taiteellisen itsenäistymisen merkiksi on kuitenkin katsottava sitä, että näistä tyylitasoista ei Nummisuutareissa näy juuri jälkeälkään ; toisaalta tälle näytelmälle luonteenomaiset henkilötyypit, niitä puhetavassa karakterisoivine peruspiirteineen, olivat itse asiassa jo nurmijärveläisessä kyläyhteisössä olemassa.

Kullervon kuvakielen funktioiden tarkastelu merkitsee tietysti esteettis-taiteellisessakin mielessä varsin rajoitettua aspektia. Käsittääkseni kuitenkin jo kuvia lähtökohtana pitäen kyetään suuntaamaan huomio seikkoihin, jotka tässä tapauksessa ovat kaikkea muuta kuin vähän merkitseviä. On mahdollista tarkkailla, miten draamallinen mielenkäynti ja elämänvire tässä Kiven luomistyön alkuvaiheessa ilmenevät draamallisen rakentelun yksityiskohdissa; edelleen voidaan päätellä jotakin siitä, miten hän tajusi ja koki draamallisen ja miten hän kaiken tuon pohjalta pyrki rakentamaan taiteellista muotoa.

Kielikuvien poikkeuksellisen näkyvä osuus näytelmässä tuskin jää. keneltäkään lukijalta havaitsematta. Lauri Viljanen on Suomen kirjallisuuden kolmannessa osassa lausunut asiasta seuraavat paljon merkitsevät sanat: "Kullervossa on eräs voimakas sanataiteen erikoispiirre, joka tuskin esiintyy Kiven omassakaan tuotannossa yhtä mahtavana: sen voi hyvin merkitä draamalliseksi sanan avarassa mielessä. Näytöksestä toiseen sankari ilmentää sieluntilansa valtavin kuvin, joiden voimasta näyttämö täyttyy alituisesti läsnä olevan, painavan ukkospilven sähköllä." Jo tältä kannalta kuvien käyttäminen jonkinlaisena kriteerinä saa tukevaa perustelua.

Toisaalta ei voi olla panematta merkille, että kuvailmaisujen aiheet kuvastelevat suhteellisen suppeata liikkumisalaa. Hallitsevina ovat barokin ja romantiikan eräät keskeiset kuvamotiivit, esim. myrsky, tuli ja valaistus. Materiaaliin sisältyy vähemmän varsinaista aistimellis-havainnollista luonnetta, sanokaamme sellaista, jota sitten tapaamme suomalaisenkin realistisen kirjallisuuden selvälinjaisesti visuaalisissa tai audiitiivisissa metaforissa ja vertauksissa. Sen sijaan niiden metaforisen painokkuuden ja käyttökelpoisuuden oli pitkä kirjallinen traditio vahvistanut, ja niiden kiinteästi tunteisiin vetoa- 
vat ominaisuudet tarjosivat edelleen mahdollisuuksia väkeväsävyisille persoonallisille kehittelyille. Kullervon kielikuvien yksilöllinen väritys, niiden aito kivimäisyys, johon kaikissa tapauksissa sisällytämme tietyn konkreettisen näkemis- ja tuntemistavan leiman, on kyllä yleisesti havaittu, ja tuskin on harhaanjohtavaa nähdä tässä piirteessä yhtä kirjailijan edessä olevan kasvun varmimmista ennusmerkeistä. Osaltansa tällaisten tyyliainesten yksilöllinen leimaisuus merkitsee tärkeää tekijää myös näytelmän kielen kannalta keskeisessä ilmaisutavan aktivoitumisessa; mutta se ei, draamallista hahmottumista yleensä ajatellen, voi muodostua primääriseksi laatuominaisuudeksi. Asia on asetettava yhteyteen sen kanssa, että jos puhumme osasista, joista draama kasvaa, meillä on oikeus tehdä näin vain määräedellytyksin. Kaikki osiutuminen tapahtuu lopultakin kokonaisuudesta käsin, ja yksityisten rakennusainesten, kielikuvienkin, niiden luonteen ja tehtävän tarkkailu voi luonnollisimmin tapahtua vain suhteessa tuohon kokonaisuuteen. Osasten ja ainesten funktionaalisuus taas antaa luvan päätellä niistä seikkoja, joihin aikaisemmin viitattiin: draamallisen mielenkäynnin ja elämänvireen ilmenemistä sekä tapaa tajuta ja kokea draamallinen.

Kuvakielen tehtäviä ja näytelmällistä tarkoituksenmukaisuutta silmällä pitäen ei ole merkityksetöntä sekään, miten kuvat määrällisesti sijoittuvat näytelmän eri kohtiin, toisin sanoen niiden erilainen tiheys. Muutama viittaus lienee paikallaan. Runsaasti kuvailmaisuja esiintyy ensimmäisen näytöksen keskellä olevassa kohtauksessa, jossa Kullervo ja Kimmo keskustelevat. Sen sijaan näytöksen alkutilanne, joka on pääasiallisesti Unnon ja hänen vaimonsa puhetta, samoin kuin loppu, Kimmon ja Nyyrikin kohtaus, jäävät tältä kannalta mielenkiinnottomiksi. Sekä toinen että kolmas näytös alkavat Kullervon laajahkolla monologilla, joka molemmissa tapaulssissa kasvaa runsaskuvaiseksi. Eniten toisessa näytöksessä kuitenkin kiinnittää huomiota Kalervon huoneeseen Kalalammille sijoitetun kohtauksen alku. Sekä Kalervo, hänen vaimonsa että Kullervo käyttävät pitkiä, metaforien ja vertausten siivittämiä puheenvuoroja; ensiksi mainitut surevat tyttärensä katoamista, Kullervo valittaa murhatyötään. Kolmannessa näytöksessä saavutetaan kuvatiheyden huippu siinä tilanteessa, jossa Kullervo, sisarenviettelyksen jälkeen kotiin saapuneena, joutuu kiihkeään sananvaihtoon omaistensa kanssa. Asiaan kuuluu, että hänen puheensa sanailun kiihtyessä muuttuu yhä näkyvämmin kuvalliseksi. 
Neljännessä ja viidennessä näytöksessä erottuvat muutamat päähenkilön vuorosanat hyvin selvästi, kun taas dialogi muuten, harvoja poikkeuksia lukuunottamatta, pyrkii pysyttelemään tyylillisesti värittömänä.

Se, että toteamme kielikuvia jossakin kohdassa käytetyn runsaasti, toisessa niukasti, ei siis toki anna aihetta pitkälle meneviin johtopäätöksiin. Parista seikasta kannattaa huomauttaa. Kuvien kasautumista esiintyy vain kohtauksissa, joissa Kullervo on mukana, varsinkin hänen omissa vuorosanoissaan. Selityksenä on tietysti hänen keskeinen asemansa näytelmässä, mutta piirre viittaa samalla huomattavassa määrin toteutettuun välittömän henkilökuvauksen tekniikkaan. Toiselta puolen kuvien erilainen tiheys saattaa olla osoituksena joissakin suhteissa yhdenmukaisesta puhetavasta, jota henkilöt tietyssä tilanteessa noudattavat. Kysymys on jollekin näytelmän kohtaukselle luonteenomaisesta, juuri siinä tavattavaa psyykkistä läikyntää ilmentävästä puheen luonteesta ja sävystä, tilannekielestä. Jo henkilöiden keskinäiset suhteet vaikuttavat dialogin muovautumiseen; niinpä Kullervo rakentaa puheensa toisin keskustellessaan Kimmon kanssa kuin kohdatessaan Nyyrikin. Edelleen voimme todeta, että toisiaan peräkkäisinä seuraavat, kuvia runsaasti tai niukasti käyttävät tilanteet ovat nekin osatekijöitä draamallista toimintaa myötäilevässä rytmiliikunnassa, näytelmän eteenpäin työntyvässä sisäisessä liikkeessä. Kun noissa tilanteissa voi ilmetä erilaisia perussuuntauksia tai -tuntoja, esim. korostunutta emotionaalisuutta tai selvää aggressiivisuutta, tai dynaamista tai staattista ilmettä, niin on todettava, että tällaisilla ei ole minkäänlaista suoranaista suhdetta kielikuvien määrään. Staattinen ilme tavoitetaan sekä kuvallisen puheen turvin että toisen kerran niukkakuvaisen rupattelun avulla. Samoin kiihkeä draamallinen kohtaus saattaa hahmottua miltei kuvattoman dialogin varaan, näin Kullervon kohdatessa Ilmarisen emännän, tai voimakkaasti kuvallisen varaan, esim. Kullervon ilmoittaessa kotiväelleen sisarensa kohtalosta.

Tietysti olisi jo mahdollista kysyä, saattaisiko kielikuvien erilainen määrä niissä kohtauksissa, joihin äsken viitattiin, osaltansa olla osoittamassa niiden painosuhteita näytelmän sisäisen liikunnan ja toiminnan rytmissä. Jos kysymykseen on vastattava myöntäen, niin kuin näyttäisi olevan todennäköistä, on saatu kosketus erääseen tapaan, jolla Kivi luomiskautensa tässä vaiheessa säätelee draamallisen liikkeen etenemistä ; laillaan se merkitsee struktuurin kannalta enemmän tai vähemmän olennaisia merkkikohtia. 
Kuvakielen tehtäviä voisi yksityiskohtaisemmin tarkastella ensimmäisen näytöksen valossa. Perustunnoiltaanhan näytös on melko yhtenäinen, vaikka siinä, kuten on käynyt ilmi, kuvien tiheys vaihtelee ja Kullervon ja Kimmon kohtaus jo sen takia erottuu ympäristöstään. Eksposition luonteen mukaisesti näytöksessä henkilöiden menneet vaiheet, näytelmällinen nykyhetki sekä eteenpäin tähtäävät toimintojen idut leikkaavat jyrkästi toisiaan. Aggressiiviset tunnot hallitsevat keskeisten henkilöiden mieliä, kasaantuvina, purkautumattomina. Unto ja hänen vaimonsa on asetettu toisiaan vastaan, yhteisenä vastavoimanaan Kullervo. Kullervon ja Kimmon kohtauksessa suuntautuvat aggressiot tietysti Untoa vastaan, mutta orjatoverustenkin välillä pyrkii syntymään konfliktin alkua. Ja näytöksen lopussa Kimmo esiintyy Nyyrikkiä kohtaan hyöklkäävämmin, kuin psykologiselta kannalta oikeastaan tuntuisi luonnolliselta.

Tuollainen draamallinen ilmapiiri on kaikkea muuta kuin edullinen henkilökontrastien selvälle ilmentämiselle kielikuvissa. Niinpä esim. Kullervolla ja Kimmolla havaitaan melkoista samansävyisyyttä. Kullervo sanoo: "- - ja tiedä että salaisuutes on kuin kätkettynä vuoren alle." Kimmo taas kerran: "Mies, muotos kauhistaa; tämä terävä ja kylmä katsanto on kärmeen." Siis drastillinen mielikuvayhdistelmä esiintyy kummassakin, sen sijaan persoonallisen laadun ero ei tunnu. Mutta toisaalta kirjailija aloittaa Kullervon ratkaisevan syventämisen näytelmähenkilönä heti alkunäytöksessä, ja sen tulee päästä ilmi siinä, että hänen puheensa erottuvat Kimmon sanoista, samoin kuin siinäkin, että hänen käyttämänsä kuvat muodostuvat monipuolisemmin paljastaviksi ja samalla tehtäviltään useammalle taholle tähtääviksi. Tämä näkyy siitäkin, että kuvilla on taipumus kasvaa. Tuloksena ei ole kuitenkaan sellaisia, jotka sävyttyisivät eeppisiksi. Draamalliseksi virittävänä tekijänä voi olla esim. väkevä1n liikkeen ilme yhtyneenä vastakohtia ilmentäviin mielikuviin: 'Tässä tukehtua tahdon ja sentähden raikasta ilmaa himoon, himoon kostoon käydä, nurin niskoin itseni viskata siihen tuulenpuuskaan, jossa kuitenkin hetken uiskennella saisin." Tyypillisiksi Kullervolle muodostuvat mahtavat syntetisoivat kuvakasautumat, joissa hän kuin ainutkertaisena välähdyksenä pyrkii antamaan sielunkerrostumiensa eri suuntiin tempovat ainekset: "Mutta näinpä itseäni kiusaan, katsel- 
lessa löyhkäävältä tienoolta onnen kaukaista maata, joka eteeni nousee, kuin korkea, kultainen hongisto, mutta toisella puolella mahdottomuuden merta. Nähdessäni tätä, kiertoilen tässä, ja ilma, jota hengitän, on kirouksen sumu ja kaasu."

Mainitunlaiset kuvasanonnat erottuvat Kullervon kerta kaikkiaan muista poikkeavaksi draamalliseksi yksiköksi. Ne jo ilmaisevat, eräänlaisesta henkisestä rajoittuneisuudestaan huolimatta, sisäistä liikkuvuutta aivan toisessa mitassa kuin kenenkään muun kohdalla ja samalla paljastavat räikeän selvästi hänen kahtiajakautuneisuutensa — henkilön, joka omaan sisimpäänsä sulkee näytelmän jyrkimmät kontrastit. Paitsi päähenkilön luonteen valottajina niillä on oma, eikä suinkaan vähempiarvoinen tehtävä struktuuria luovalta kannalta. Erään puolen, joka ehkä on keskeisimpiä ja jonka jo ensimmäisenkin näytöksen perusteella voi havaita, Lauri Viljanen tuo hienosti ilmi tulkitessaan, aikaisemmin mainitussa yhteydessä, Kullervon kuvien luonnetta: "Mutta ne eivät ole lyyrisiä monologeja: yksinäinen kiroava titaani ei lausu niitä silmät ummessa, itseensä vaipuneena. Kaikkien muiden näyttämöllä toimivien täytyy määrätä suhteensa häneen ; hän vetoaa hellittämättömästi heidän tunteisiinsa, samalla kun sulkee kauheimmat tunteet poveensa _ _." Tosiasiallisesti hän kokoaa ja tihentää kuviinsa jotakin huomattavasti yli sen, mikä suoranaisesti koskee vain häntä itseään. Alkunäytöksessä ne kuin kärjistävät ja huipentavat aggressioiden täyttämän ilmapiirin, sulkevat itseensä ydinaineksen kaikesta siitä, mitä eri henkilöiden suhteista, yleensä tämän näytöksen perustavimmista käyteaineksista, käy ilmi, ja näin ne luovat patoutuneen jännittynyttä taustaa niille purkautumille, joita tapahtumien edetessä on odotettavissa.

Lienee nïn, että draamallisen sanonnan pienoispiirteiden tutkistelua ei yleensä voine sanoa varsin antoisaksi. Dynaamiseksi määräytyvässä kielen kentässä, jota tunteiden ristiriidat ja väkevät tahdonpyrkimykset säätelevät ja joka kuvastaa toimintaa ja tähtää toimintaan, eivät pääse oikeuksiinsa herkästi ja värikkäästi vivahduttavat sanonnan ominaisuudet, joissa taas eepikon kieltä luova nerokkuus voi löytää omimman alansa. Sen sijaan saattaa näytelmädialogissa melkoisesti kiinnostaa jo se, miten kirjailija lauseittensa ja niiden ryhmittämisen avulla luo pienempiä tai laajempia kokonaisuuksia, joissa voi aavistella jotakin hänen päämääriensä kannalta tarkoituksenmukaista. Asian selvittäminen Kiven esikoisnäytelmän kohdalla ei 
varsinaisesti kuulu tämän kirjoitelman piiriin. Vain muuan seikka, joka liittyy kielikuviin, saakoon hiukan huomiota.

Jos tarkastelee kuvien paikkaa lauseissa, lähinnä Kullervon puheenvuoroissa, joutuu toteamaan, että ne tavallisesti sijoittuvat painokkaaseen asemaan ja luonnollisimmin, joskaan ei yksinomaisesti, lauseiden loppuun: 'Unto, kuinka kauvan povessani säästelen sua kohtaan vihani tulta?" Puhe pyrkii tällöin saamaan huipentumaan tähtäävää rytmi-ilmettä. Jos taas kuvat — tai kuva — täyttävät koko lauseen tai virkkeen, on kysymyksessä yleensä jonkin virkettä laajemman muotokokonaisuuden päättävä huijentuma; esim. "Malta: miten elää tässä palvellen sukuni surmaajata? - Mutta Unnolle ei toki hyötyä työstäni oleman pidä, sillä orjana en hälle siivosti askartele, vaan ylpeästi tässä ympärillä käyskelen ja katselen muiden raatamista ja vaiti olen. Mutta tämä sappea tekee, polttaa vertani ja silmät päästäni puhkaista tahtoo." Se psyykkmen linja, joka monta kertaa hallitsee Kullervon vuorosanoja, näkyy tästä jo selvänä: lähtökohta on ulkonaisissa oloissa, jossakin varsin konkreettisessa, päätekohtana on oman tuskan, kärsimysten ja ristiriitojen esiin purkaminen, mikä tapahtuu metaforisin keinoin. Laajat puheenvuorot, kuten sekin josta edellä oleva sitaatti on otettu, saattavat tähdätä useaankin kuvan avulla aikaansaatuun huipentumaan, jolloin muodostuu väkevän sisäisen altoliikkeen kannattama kokonaisuus. Viime kädessä on kysymys siitä, että samanlainen rakenteen prinsiippi, joka toteutuu lauseessa tietynlaisena rytmillisenä ilmeenä, etsii muotoaan myös laajemmissa kokonaisuuksissa. - Vain aidosti draamallinen näytelmäsankari voi mielenkäynnilleen tavoitella tuollaisia ilmaisumuotoja.

Alkunäytöksessä esille tulleen perustalta lähtee liikkeelle muuttuva ja dynaaminen aines Kullervon sisäisessä draamassa. Hänessä tapahtuu Hamletiin verrattavaa epäsympaattista luonteen turtumista, paatumista, raaistumista, kuten tukimuksessa on huomautettu. Olemme tekemisissä toiminnan linjaa keskeisimmällä tavalla suuntaavien tekijöitten kanssa. Tosin ajatus kostaa omaisten kohtalo on jo merkinnyt paaduttavan kehityksen alkua. Kuitenkin vasta tehtyään pikaistuksissaan tapon ja turmeltuaan tietämättään sisarensa Kul- 
lervo on todella rikkonut järjestyneen ihmiselämän ikuisia lakeja vastaan. Kirjailija on sankarinsa sielullista muuttumistapahtumaa ajatellen halunnut näyttää nuo teot välttämättömiksi. Vasta sen moraalisen turtumisen takia, minkä ne aiheuttivat ja mitä vielä täydensi sydämetön välienrikkominen omaisten kanssa, Kullervo kypsyi kykeneväksi suorittamaan myös harkitun joukkomurhan, jollaiseksi hänen kostonsa oli muodostuva.

Draamallisesti keskeisimmän tapahtumisen alue on siten sellaisella suunnalla, että dialogin moni-ilmeisyys, sen laaja-alainen psykologinen paljastamiskyky, olisi katsottava mitä välttämättömimmäksi. Päähenkilön ironis-kyyninen puhetapa onkin suurin piirtein katsoen merkittävä jatkuvan paatumisen ja raaistumisen sanallisen ilmaisemisen kehykseksi. Itse hän korostaa asennettaan, tavallaan vakuuttelee itselleen sitä lähtökohtaa, josta kiinni pitäen ja jonka mukaisesti edeten vain tarkoitettu sielunkehitys ja samalla laillaan draaman jatkuvasti tihentyvä voimalataus on mahdollinen; hän sanoo esim. näin: "Mitä tapahtuu ei sydän tuntea saa, vaikka vuodattaisin oman kantajani veren; sillä suloista on mieltä karaista ja kiukkuiselle onnelle kiusaa tehdä. Sydän kivestä ja koura rautainen, ne täällä ovat parhaat edut."

Dialogin rakentamistaito ei kuitenkaan vielä riittänyt siihen, että päähenkilön sisäinen kehitys pääsisi johdonmukaisesti ilmi puhetavassa, nimenomaan sen jatkuvana muuntumisena tarkoituksenmukaiseen suuntaan. Mutta tärkeintä lieneekin todeta, että tämän vaiheen päätös, tilanne, jossa Kullervo ilmoittaa sisarensa kohtalosta, on tyylillisin keinoin ja erityisesti kuvien käyttöä ajatellen mitä selvimmin merkitty, kuten aikaisemmin jo viitattiin. Kyynispateettinen vuorosanojen kehittely viedään niin pitkälle, että mitään muuta näytelmän kohtaa ei voida siihen verrata. Kullervo puhuu näin: "Merkitty juhta! Tämä sana, niinkuin kärmeen kieli sydäntäni pistelee ja myrkyllänsä sekoittaa miehen aivon. - Sama leikki aina, mihin käännyn, mutta silmän-iskun, jota ei nauraa tule, siinä leikissä näyttää tahdon. - Tänne mustat pilvet joka ilmasta ja kauhistuksen yö, jossa huhkaimena Kullervo kuolon sanomia huutelee! Kuulkaat, kuulkaat mitä teille ilmoitan: Tyttärenne Ainikki, joka eksynyt oli, itsensä vihasen kosken kuohuun viskasi, ja nieli hänen ahne pyörre." -— Ja vähän myöhemmin: "Pimeys tulkoon pimeyden päälle! Loppuun asti teille asian kertoa tahdon, ja kuuluu se näin: Hän joka 
immen päälle iski niinkuin kotka ja väkisten neitsyytensä kunniankruunun vei, ken oli hän? Kalervon ainoa poika hän oli.'

Ymmärrettävästi sopisi pohtia sitäkin, mitkä ilmaisun välineet tässä puhuvat voimakkaimmin. Joka tapauksessa on selvää, että metaforiikan tehosta ei ole haluttu tinkiä vähääkään; se voidaan katsoa miltei ylimitoitetuksi. Samalla kuvat osoittavat selvimmin sen asteen, johon Kullervo kehityksessään on päätynyt: kovettuminen ja raaistuminen on näytetty täysimmillään, peto on astunut ihmisen sijaan. Toisaalta kuvien hahmottamisessa on osaksi poikettu siitä periaatteesta, joka päähenkilön kohdalla on näyttänyt säännönmukaisimmalta: hän ilmaisee kuvin myös todella tapahtunutta; siis abstraktissielullisen asemesta halutaan kuvan avulla suunnata huomio varsin konkreettiseen. Tällaisen kohdalla retoris-pateettinen paisuttelu helpoimmin alkaa näyttää taiteellisesti arveluttavalta. - Mutta näkyvämmin tuskin olisi voitu draaman ratkaisevinta käännekohtaa osoittaa.

Vaikka Kivi näytelmässään toisteleekin joitakin kuvien aiheita, hän ei niiden käytössä pyri kiinteään johdonmukaisuuteen. Metaforisten välähdysten välittämä kosketus Kullervon sielunkenttään on kirjailijan kannalta tärkeämpää kuin tiettyjen kuvatyyppien tai -motiivien kehittelevä, draamallista linjaa hahmottava käyttö. Myrskyaihe kuitenkin herättää enemmän kiinnostusta kuin muut; näin siksi, että se mieleenjäävällä tavalla liittyy päähenkilön sielunkehityksen erääseen ratkaisevaan vaiheeseen.

Mainittua aihepiiriä edustavia kuvia, joihin usein sisältyy myös valaistuksesta muistuttava piirre, tavataan Kullervon vuorosanoissa muutamia näytelmän eri kohdissa. Viimeisen näytöksen loppukohtauksessa hän sanoo Ilmariselle sanat, jotka tuossa vaiheessa, hänen tehtyään jo tilin elämänsä kanssa, muodostuvat sanottavaltaan hyvin merkityksellisiksi: "Silloin talostasi siirryin pois, ja tuntui, kuin olisin uneksunut. Ja siitä asti on eloni ollut myrskyinen yö, koska ukkoinen käy, kalliot runnotaan, metsät palaa, ja korkeus joka hetki vaeltajaa uhkailee, joka kamoen laaksossa käy." - Se on väkevä kuva, joka ei kuitenkaan enää, ajallisesti taaksepäin katsovana, sisällä varsinaisia draamallisia virikkeitä. Sisäisestä ihmisestä se sen sijaan leikkaa todella laajan kaistan sekä pituutta että syvyyttä. Mutta vaikka sen jokainen yksityiskohtakin puhuu paljossa rikkoneen hädästä katoamattomien mahtien edessä, on toisaalta korostettava kuvailmaisun 
hämmästyttävää havainnollisuutta. Tämän yhteydessä on aihetta huomauttaa sellaisesta kielikuvien tehtävästä, johon aikaisemmin ei ole puututtu. Toisaalta näynomaisuudessaan, toisaalta esineellisyydessään tuollaiset kuvat rakentavat draaman sisäistä maailmaa syventämällä ja avartamalla tilavaikutelmia. Psyykkisen kokemuksen ilmaisemiseen yhdistyy kuvitteellisen tilan väljentäminen aina taivaan korkeuden ja laaksossa käyvän vaeltajan ääripisteisiin.

Tämä kuva puhuu kyllä jo sellaisenaankin tarpeeksi selvää kieltä. Mutta se avautuu vielä, ehkä voisi sanoa, monumentaalisemmaksi, jos sen yhteyteen vedetään eräs edellisen näytöksen kohta, johon sen liittää yhteinen kuvamotiivi. On hankala päätellä, onko tekijä todella tarkoittanut nuo kohdat sisäiseen riippuvaisuussuhteeseen toistensa kanssa. Jos niin olisi, se merkitsisi tässä näytelmässä, struktuuria koskevan näkemistavan kannalta, käsittääkseni poikkeuksellista piirrettä.

Siinä vaiheessa Kullervo on saavuttanut päämääränsä, hän on kostanut. Hän on sytyttänyt Kalervon talon tuleen ja noussut vuorelle ihailemaan kättensä työtä. Mutta siellä syöksyvätkin hänen mieleensä muistot pahoista teoista, joihin syypääksi hänen on nyt itsensä tunnustettava. Hän kertoo Tieralle: "Silloin _ _ huokauksen kuulin, kuin monen kosken pauhun, pohjoisesta käyvän; myrskynä se ohitseni meni, murheellisesti valittaen ja valituksellansa pimeän avaruuden täytti. Männyt vuoren kiireellä, kuivettuneet, sammaleiset, vapisit, ja vinguit tämän vihaisen vihurin kynsissä ja kirkuen yösijoiltansa kotkat pakenit. Ja kostonhuudon päälleni tässä myrskyssä mä kuulin ja sentähden kamo synkeä mua painaa, enkä päältäni sitä viskata voi." Kostotyön seurauksena on vain kaiken ennen tapahtuneenkin tunteminen hirvittävänä, sovittamattomana taakkana ja kauhistavana tyhjyytenä: "— — mihin käyn nyt enään käsin? Tyhjyydessä kauhun mieleni huohuttaa, hirmun merta pohjatonta mittailee, mutta eipä pohjaa löydä — —."

On tarpeetonta pohtia, onko myrskyn kokemus jonkin ulkonaisestikin koetun liioittelua, onko se kuvittelua tai vain harha-aistimus. Se puhuu runollisena kuvana. Jos ajatellaan Shakespearen näytelmissä esiintyviä myrskyn kuvauksia, niin voidaan ilman muuta todeta, että esim. Myrskyssä ja Othellossa tavattavilla ei ole mitään liittymäkohtia Kullervoon. Sen sijaan on täysin aiheellista viitata Kuningas Learin kolmannen näytöksen nummikohtaukseen, jossa päähenkilön mielipuolista tuskaa säestää raju myrsky, todellinen 
"taivaan raivo". Tuo pauhaava ja vinkuva rajuilma kiinnostaa meitä vähemmän, enemmän jokin muu: purkaessaan syytölksiään, nöyryytystään ja uhmaansa sanoiksi kuningas Lear sitoo sisäisen raivonsa mielikuviin, joita ulkonainen myrsky hänessä synnyttää. Yhteistä Kiven näytelmän kanssa on siten se, että keinot katkerimman inhimillisen kokemuksen ilmentämiseksi ovat ehkei samat, niin kuitenkin samansuuntaiset. Kun Kullervo kuitenkin ilmaisee tuskansa tavallaan välittömästi, siis kertoo kokemansa, niin Shakespeare tuollaisen lisäksi draamanomaisesti havainnollistaen sekä levittäytyy että porautuu saadakseen ilmi sankarinsa hädän koko kauheuden.

Mainittu Kiven näytelmän kohta on joka tapauksessa järkyttävimpiä ellei järkyttävin, mitä Kullervon suuhun on pantu. Se on hänen tapauksessaan äärettömästä tuskasta esiin pusertuva tunnustus omasta pienuudesta ja ikivaltojen suuruudesta, kuningas Fjalarin tunnustukseen verrattava. Samalla tunkeutuu ilmi päähenkilön sielun väkivalloin tukahdutettu puoli, se jonka hän itseään paaduttaessaan ja kovettaessaan oli halunnut painaa kuulumattomiin, mutta joka nyt salattuja, meille tuntemattomia teitä on kypsynyt ratkaisuun. Kiven draamallisen muotokokemuksen kannalta on ymmärrettävää, ettå Kullervon sisäisen elämän kontrastisten ainesten tasapainoon saattaminen vaati tämän sisäänpäin kääntyneenäkin laillaan huipentavan purkauksen. Kuvallisen kehittelyn voimassakin se muistuttaa sitä käännekohtaa, johon turruttava ja raaistava kehitys oli johtanut. Erikoista on siltä kannalta, miten Kivi käsitti draamalliset ilmaisumahdollisuudet, että hän taas turvautui jotenkin yksipuolisesti kuvaan, oikeammin kuvapaisutteluun. - Käsitelty kohta on merkkinä Kullervon elämän kääntymisestä uudelle tielle; muutos vavahdutti hänen olemustaan sydänjuuria myöten. Viimeisen näytöksen myrsky-aiheinen kuva, josta aikaisemmin oli puhe, osoittaa tuon tien päätekohdan. Ihmisen, olevaisen ja jumalallisen suhteista, ihmiselämää hallitsevista ääripisteistä jotakin oli kirkastunut kestäväksi elämäntotuudeksi, jonka paine Kullervon kohdalla kuitenkin jätti jäljelle vain itsensä tuomitsemisen mahdollisuuden.

Aikaisemmin on ohimennen mainittu tilannekielestä, siis jollekin kohtaukselle luonteenomaisesta puhetavasta, jonka muotoutumiseen esim. kuvien tiheydellä samoin kuin niiden laadullisilla ominaisuuksilla on osuutensa. Jos ajatellaan erityisesti Kullervoa tältä kannalta, voi sanoa hänen sopeutuneen muiden henkilöiden puhetapaan kol- 
messa ensimmäisessä näytöksessä melko hyvin, mikä ei tietystikään estänyt yksilöllisten piirteiden esillepääsyä. Tuo ironinen ja kyyninen ilmekään ei ollut yksinomaan hänelle ominainen, ajateltakoon esim. Ajatarta ja Kalervoa. Silloin kun Kullervo ilmoittaa sisarensa kohtalosta, tapahtuu kuitenkin selvä muutos. Seuraavissa näytöksissä hän puhuu tavallaan toista kieltä kuin kostajatoverinsa tai Kimmo tai näytelmän lopussa esiintyvät Väinämöinen, Ilmarinen ja Lemminkäinen. Tällainen kehitys on yhteydessä siihen, että Kullervo sentään pitkälle tunsi olevansa yhteisön jäsen ; puhetavan erilaisuudet ilmensivät henkilövastakohtia, ei enempää. Kolmannen näytöksen lopusta lähtien kontrastisuhteet laajenevat. Henkilövastakohtien rinnalle ja niitä tärkeämmäksi tulee koko elämäänasennoitumista koskeva kontrasti, sen seurauksena kontaktin menettäminen ihmisiin ja lopulta täydellinen eristäytyminen. - Kuvakielen osuudesta ratkaisevassa kolmannen näytöksen kohtauksessa on ollut puhe. Myöhemminkin kuvien merkitys tässä hahmotettua suuntaa ajatellen muodostuu huomioonotettavaksi. Kullervon eräät pitkät vuorosanat erottuvat jo kuvien määrän takia entistä selvemmin ympäristöstään. Lisätekijäksi tulee niiden kvaliteetin suhde eri henkilöillä. Jyrkimmin poikkeavat toisistaan Kullervon ja Nyyrikin kuvat. Pääasiana pysyy joka tapauksessa se, että päähenkilön omaleimaisuus kaikkien muiden vastakohtana terävöityy. - Ilmeisesti tekijä tuossa kaikessa halusi toteuttaa varsin oikeaoppista draamallista ajattelutapaa, vaikka näytelmällinen verenkäynti pyrkiikin kahdessa viimeisessä näytöksessä kovin tuntuvasti laimenemaan.

Kullervon kuvakielen tarkastelu osoittaa mielestäni selvästi, että kirjailijalle oli paljastunut — nähtävästi esikuviensa ansiosta —, miten merkityksellinen osuus keskittävällä ja tiivistävällä, kärjistävällä ja eteenpäin tähtävää jännitystä luovalla ilmaisulla oli draaman keinovarojen joukossa. Hän näki sellaisen ehkä liiankin yksipuolisesti kielikuvassa. Tämän mukaisesti hän pyrkii saamaan jo yksityisen kuvankin draamallisesti virittyneeksi sitomalla siihen vastakohtaisuutta ja ristiriitaisten mielentilojen läikettä kuvastavia puolia. Tarpeen tullen hän tosin käytti myös kansanomaisen arkikielen 
mukaisia lyhyitä vertauksia sekä lyyrisiksi leimautuneita kuvailmaisuja. Vielä tärkeämpää on, että hän ilmeisesti hyvin tietoisesti alisti kuvat palvelemaan erilaisia tehtäviä: avaamaan syvimmälle valottavia näkymiä varsinkin päähenkilön sieluun, luomaan kohtauksiin atmosfääriä, ilmentämään eteenpäin vyöryvää liikettä, suuntaamaan kielen rytmi-ilmettä, muovaamaan sanonnan jaksoja muodostuvia kokonaisuuksia jäsenteleviksi hahmoiksi, merkitsemään . huipentaen toiminnan ratkaisukohtia jne. Siten kuvakieli osaltaan tuki ja täydensi henkilökuvausta, mutta muodostui luontevasti myös muotoa ja struktuuria rakentavaksi tekijäksi; mitään toista Kiven näytelmää ei tässä suhteessa voine asettaa Kullervon rinnalle. Tuo kaikki tapahtui sellaisin tavoin, että ymmärrämme tekijän täydellisesti tajunneen, mitä draamallinen, jokin toiminnan ytimenä oleva ja erilaisin muodoin ilmentyvä peruselementti näytelmässä merkitsi. Toisaalta kannattaa muistaa, että kuvat olivat kenties hänen taiteellisesti omaperäisin lisänsä Kullervon tarinaan ja että me niiden kohdalla eräissä yksityiskohdissa epäämättömästi aavistamme voitollisen, nerollisen runoilijanhengen läsnäolon.

Mutta meidän on tarpeetonta ummistaa silmiämme siltä tosiasialta, että kuviinkin ja niiden käyttöön tulivat vaikuttamaan ne hankaluudet, joita Kalevalan taruaihe dramatisoijalleen asetti. Niinpä voimme tietenkin myöntää, että juuri metaforat ja vertaukset välittävät suorasukaisimmin kosketusta näytelmän jyrkimpien kontrastien ja ristiriitojen kenttään; niiden typistäminen ja karsiminen — jos sellaista voi edes ajatella — rikkoisi siten draamallisessa liikunnassa ja kehittelyssä jotakin aivan keslieistä. Mutta kaikesta huolimatta voi tulla mieleen sellainenkin ajatus, että tämä tunnoiltaan ja sisällykseltään melko samansävyinen metaforiikka, osaksi suurisuuntaisen muotokielen merkkejä tavoittelevana, pyrkii omalla tavallaan kompensoimaan tuon alun perin eeppisen sankarin sisäistä suppeaalaisuutta, ennen kaikkea hänen rajoittuneisuuttaan näytelmähenkilönä, josta Kivi varmaan oli hyvin tietoinen. Toisaalta halu varautua mahdollisimman läheisesti alkuperäisen runon sisällykseen, toisaalta pakko muotoilla ja tehostaa näyttämövaikutustakin silmällä pitäen eivät olleet lähimainkaan riidattomasti yhteen sovitettavissa.

Joltakin kannalta kuvien näkyvä sijoittelu puheenvuoroihin voidaan, tosin aivan yleisin piirtein katsoen, asettaa rinnakkaiseksi myös tiettyjen melko konstruktiivisten rakennetekijöitten kanssa, jotka 
kyllä olivat tunnetusti koetellusti draamanomaisia; niidenkään kohdalla ei toki taiteellisesti ratkaisevaa ole se, mitä käytetään, vaan miten. Ajateitakoon traagisten ja koomisten, staattisten ja dynaamisen, realistisempien ja sadunomaisempien, konkreettisten ja abstraktisten ainesten vastakohtaa ja vuorottelua sekä tyylitasoja, eräitä mainitakseni. Rajun kuvitteellisen ja elämyksellisen eron Kivi on varmasti vaistonnut jo esim. ajankokemuksessa, kun lähtökohtana oli runon välittämä tarunomaisessa menneisyydessä päättynyt elämäntarina, johon vielä epiikan kertoja asenteensa mukaisesti oli liittänyt omat etääntyvät perspektiivinsä - ja päämääränä oli luoda illusorinen näyttämöllinen nykyhetki, saada aikaan välittömästi avautuva toiminnan virta ja sitä eteenpäin kannattava liike. Terävien sommittelujen, väkevien varjostusten ja kontrastien synnyttämä liikevaikutelma, jonka aikaansaamisessa shakespearelainen näytelmäkoneisto tarjosi apuaan, sai osoittaa käyttökelpoisuutensa, silloin kun "toiminnan virran" luonteva johtelu ja toiminnan välitön draamallinen kaareutuminen eivät ottaneet luontuakseen. Ei ole pidettävä varsin ihmeellisenä, vaikka noiden keinojen samoin kuin kuvakielen yhteydessä on tuntevinaan hiukan väkinäisen hahmottamispakon jälkiä.

Lopuksi on todettava, että Kullervo joka tapauksessa jo näyttää Kiven "todelliseksi dramaatikoksi", käyttääkseni Eino Krohnin sanontaa tutkielmassa Aleksis Kiven näytelmien rakenteesta; siinäkin puhuu täysin vakuuttavana hänen "synnynnäinen draamallinen tajunsa". Tähän puoleen onkin vedottava sitä suuremmalla syyllä, kun tiedämme hänen teatterin tuntemuksensa miltei olemattomaksi. Asian tekee vain vieläkin ihmeellisemmäksi se, että muistamme kirjailijan olleen eeppisenkin muodon ja tyylin täydellinen hallitsija. Täysin oikeutetusti voimme siten puhua myös todellisesta eepikosta ja synnynnäisestä eeppisen tajusta. Sen pohtiminen, onko Kivessä ensi sijalla eeppinen vai draamallinen taiteilijanlaatu - unohtamatta tietysti lyyristäkään, voi tuskin muodostua erikoisen hedelmälliseksi. Jonkin lajinomaisesti olennaisimman ja tyypillisimmän tavoittaminen kummallakin suunnalla, mikä maailmankirjallisuuttakin ajatellen näyttää peräti harvinaiselta, ei voi perustua muuhun kuin täysin poikkeukselliseen ja vaistonomaiseen kykyyn tajuta yleensä runouden muoto- ja tyyliominaisuuksia, taiteellisen struktuurin perustavia 
aineksia, ja toteuttaa niitä omassa luomistyössä. Nähdäkseni tämä puoli ei vieläkään ole saanut osakseen ansaitsemaansa huomiota. Tutkimuksella tulee sen takia edelleen olemaan tehtävää Aleksis Kiven tuotannon parissa.

\section{Leevi Valkama: Die Funktion der Bildersprache in Kullervo von Aleksis Kivi}

Kullervo (1864) ist das Erstlingswerk von Aleksis Kivi. Der Stoff zu diesen Werk, der ersten Tragödie der finnischsprachigen Literatur, entstammt dem Kalevala. Schon seiner literarhistorischen Stellung wegen hat es verständlicherweise besonderes Interesse in der Forsclung erweckt. In seinem dramatischen Aufbau lelınt es sich an das Werk Shakespeares an, besonders Hamlet lässt sich als wichtigstes Vorbild nachweisen. Der grosse englische Dramatiker hat auch u.a. den Stil beeinflusst. Kivi bewegt sich in seinem Drama auf bekannten Stilebenen. Von Shakespeare hat Kivi offenbar auch gelernt, wie wichtig die Funktion von verdichteten und zugespitzten Ausdrücken für die dramatische Darstellungsweise ist. Der finnische Schriftsteller sah solche in erster Linie und vielleicht zu einseitig in metaphorischen Ausdrucksmitteln. Er gebraucht diese auch besonders in diesem Schauspiel auffällig reichlich, und sie machen sich schon durch ihre stark persönliche Wirkung bemerkbar. Auf eine dramatisch abgestellte Verwendung weist schon der Umstand hin, dass der Schriftsteller danach strebt, auch die zahlreichen Einzelbilder in dramatische Gestimmtheit zu bringen, indem er Züge mit diesen verband, die kontrastierende und widerspruchsvolle Gemütszustände abspiegeln. Meist enthalten die Repliken der Hauptperson, Kullervos, Bilder; in empörter oder verärgerter Stimmung ergeht er sich andauernd in starken Metaphern und Vergleichen, die jedoch in gewissem Umfang zu Monotonie neigen. Auf verschiedene Weise veranschaulichen die Bilder die auf eine weitere Entwicklung gerichtete Funktion und Bewegung des Dramas: teils reichlich, teils sparsam ist die Verwendung von Bildern in den Szenen, die abwechseh können, die Bilder zielen auf ryhthmischen Ausdruck der Sätze, sie verbinden Repliken zu einer Art bildakzentbeherrschten Ganzheit und bedeuten in ihrer Zuspitzung Wendepunkte der Handlung. So werden sie, ausser dass sie zur Vertiefung der Charakterzeichnung beitragen, zu Faktoren, die in beachtlicher Weise Aufbau und Struktur des Dramas bestimmen. Anderseits ist zu beachten, dass aus der Verwendung der bildlichen Ausdrücke auch hervorgeht, dass der Schriftsteller nicht völlig der Schwierigkeiten Herr geworden ist, vor denen er von Anfang an bei der Umwandlung des epischen Erzählstoffes in ein Drama stand. 